\title{
Growth and Instability in the Land Use Categories of different Agro-climatic Regions of Rajasthan
}

\author{
Thanuja, P. ${ }^{1 *}$, G.L. Meena ${ }^{1}$, Hari Singh ${ }^{1}$, Latika Sharma ${ }^{1}$ and B. Upadhyay ${ }^{2}$ \\ ${ }^{1}$ Department of Agricultural Economics and Management, MPUAT, Udaipur, Rajasthan, India \\ ${ }^{2}$ Department of Statistics, MPUAT, Udaipur, Rajasthan, India \\ *Corresponding author: thanujapnt@gmail.com (ORCID ID: 0000-0001-7690-5568)
}

Received: $27-09-2021$

Revised: 22-11-2021

Accepted: 06-12-2021

\begin{abstract}
Land use is complex phenomenon technological change, climatic changes influences land use changes over time period. Rajasthan, the largest state in geography and varied climatic factors makes it important to understand the land use across the state. Present study aimed at understanding the growth and instability in the different land use categories of Rajasthan with special reference to ten agro-climatic regions of the state. Compound growth rate and cuddy della valle instability index was used to analyse the data. Secondary data collected since after the implementation of second land policy (1973 till 2018). Area under forest and non-agricultural uses as well as area under cultivation in all regions has reported significant positive growth rate whereas area under barren unculturable land and permanent pastures \& other Grazing land in almost all agro-climatic regions of Rajasthan has significantly decreased. The land uses category under tree crops \& groves reported high instability and swollen data in all study regions for the present study period.
\end{abstract}

\section{HIGHLIGHTS}

(0 The present study was based on ten different agro-climatic regions of the Rajasthan state.

(- Area under forest and area sown more than once has increased significantly over the study period concluding the ecological and agriculture favourable across the state.

Keywords: Land use dynamics, land policy, compound growth rate, instability index

Land is a basic input for agriculture and it occupies an important position among all the resources required for a modern economy (Ramasamy et al. 2005). Land use is any kind of permanent or cyclic human intervention to satisfy human needs, either material or spiritual or both, from the complex of natural and artificial resource, which together are called "land" (Vink, 1975). The existing land use pattern at any point of time has been evolved as a result of the action and interaction of various factors such as the physical characteristics of land, the institutional framework, the structure of other resources such as capital, labour etc., available land and the location of the region in relation to other aspects of economic development.

Rajasthan with an area of 3,42,239 sq kms. (10.4\% of India's total geographical area) stands first in geographical area among all states. Land use in total cropped area has increased by 1.16 percentage (Statistical abstract of Rajasthan, 2019). It is important to understand land use pattern across the different regions of the state so that to develop future research strategy on land use planning and land use policies. Keeping this in view an attempt was made in this research to analyse the growth and instability in area of different categories of land use in Rajasthan.

How to cite this article: Thanuja, P., Meena, G.L., Singh, H., Sharma, L. and Upadhyay, B. (2021). Growth and Instability in the Land Use Categories of different Agro-climatic Regions of Rajasthan. Economic Affairs, 66(04): 599-604.

Source of Support: None; Conflict of Interest: None 


\section{MATERIALS AND METHODS}

Study pertains to various agro- climatic regions of Rajasthan state. For the present study, the secondary data since 1973 (after first land policy 1950-1972 and at the beginning of second land policy 1973) till 2017-18 (most recent data available) was collected from the various sources such as Basic Statistics (Government of Rajasthan), Statistical Abstracts, Agricultural Statistics at a Glance, Indiastat.com. Analytical tools used were compound growth rate and Instability index.

Compound growth rate: Growth of any variable indicates its past performance. It helps to understand trend in variable over period of time.

$$
\begin{aligned}
& Y_{t}=Y_{0}(1+r)^{t} \\
& \log Y_{t}=\log Y_{0}+t \log (1+r) \\
& r=(\text { Antilog }(1+r)-1) \times 100
\end{aligned}
$$

Where, $Y_{t}=$ Land under particular category at $t^{\text {th }}$ year, $Y_{0}=$ Land under particular category at base year, $r$ = Compound growth rate, $t=1,2,3 \ldots \ldots$. years.

The ' $t$ ' test was applied to test the significance of $(1+\mathrm{r})$

Instability of land use : (IIN) is defined as (by Cuddy-Della Valle)

$$
I I N=C V \times \sqrt{ } 1-R^{2}
$$

Where $C V$ calculated as $C V=(\mathrm{SD} \div$ Mean $) \times 100$ Where, S.D. = standard deviation

\section{RESULTS AND DISCUSSION}

Growth rate in different land use categories of arid western zone depicted positive and significant growth rate in area sown more than once (6.62) followed by forest area (2.44), total cropped area (0.84), net area sown (0.44) and area under nonagriculture uses (0.19). Significant decrease was reported by land under cultural wastes and old fallows (0.81).

Growth in land use categories of Irrigated western zone delineated that significant increase in the area was observed in forest (4.73) followed by area sown more than once (3.32), old fallows (2.90), total cropped area (1.4) and area under non-agriculture uses (0.36). Decreased growth was reported by permanent pastures and other grazing land (-3.21), barren uncultivated land (-2.56). Decreased area of barren uncultivated land might have shifted to the non agriculture uses which reported positive growth rate over study period.

Growth in land use categories of hyper arid partially irrigated zone reported that, significant and increased growth rate was noticed in land under tree crops and groves (10.25), area sown more than once (10.02), area under non-agricultural uses (2.39), forest (1.94), total cropped area (1.66) and net area sown (1.17). Significant decrease in area was noticed in land under cultural wastes (-1.15) and barren uncultivated land (-0.56). Highest growth reported under miscellaneous tree crops and groves might because of the area covered by this category in Jaisalmer district was highest which contributed to the growth. Agriculture has positive growth in present zone.

Compound growth rate of land use categories in transitional plain of inland drainage reported positive annual growth of area in area sown more than once (4.48), forest (2.09), area under non agricultural uses (0.73), old fallows (0.71) and total cropped area (0.69). Decreased growth in area was reported under land use categories such as land under tree crops and groves (-2.12), current fallows (-1.06) barren uncultivated land (-1.28), permanent pastures and other grazing land (-0.37).

Growth rate in transitional plain of alluvial plain of luni explained that, growth rate for all categories was found significant except for land under tree crops and groves. The area sown more than once $(1.69 \%)$ followed by land under cultivable wastes $(1.48 \%)$, total cropped area $(0.79 \%)$, net area sown $(0.26 \%)$, area under non agriculture uses $(0.58 \%)$ and forest $(0.53 \%)$. Significant and decreased growth rate was observed under land categories such as, current fallows (1.3) old fallows (0.34) and barren uncultivated land by 0.4 percent.

Growth in land use categories of semi arid eastern plain reported the highest growth rate in forest area with increased growth rate of 1.33 percent annually. This study also showed increased growth rate of area under non agriculture uses (0.89), total cropped area (0.92), net area sown (0.23). The other categories like, current fallows (1.42), land under cultivable waste land (1.29) as this land might have converted 
Table 1: CAGR of Land use categories in agro climatic zones of Rajasthan

\begin{tabular}{|c|c|c|c|c|c|c|c|c|c|c|}
\hline & 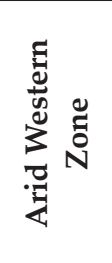 & 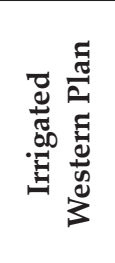 & 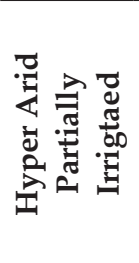 & 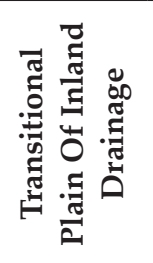 & 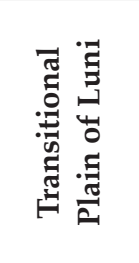 & 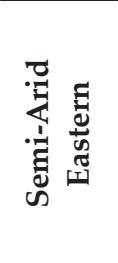 & 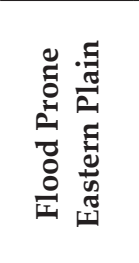 & 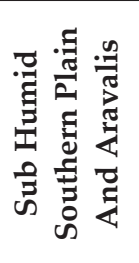 & 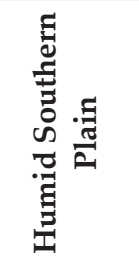 & 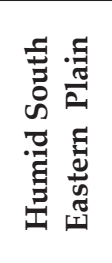 \\
\hline Forest & $\begin{array}{l}2.44^{* *} \\
(0.14)\end{array}$ & $\begin{array}{l}4.73^{* *} \\
(0.61)\end{array}$ & $\begin{array}{l}1.94^{* *} \\
(0.15)\end{array}$ & $\begin{array}{l}2.09^{* *} \\
(0.18)\end{array}$ & $\begin{array}{l}0.53^{* *} \\
(0.05)\end{array}$ & $\begin{array}{l}1.33^{* *} \\
(0.05)\end{array}$ & $\begin{array}{l}1.34^{* *} \\
(0.03)\end{array}$ & $\begin{array}{l}0.56^{* *} \\
(0.08)\end{array}$ & $\begin{array}{l}1.42^{* *} \\
(0.16)\end{array}$ & $\begin{array}{c}0.66^{* *} \\
(0.1)\end{array}$ \\
\hline Area under non-Ag. uses & $\begin{array}{l}0.19^{* *} \\
(0.14)\end{array}$ & $\begin{array}{l}0.36^{* *} \\
(0.04)\end{array}$ & $\begin{array}{l}2.39^{* *} \\
(0.14)\end{array}$ & $\begin{array}{l}0.73^{* *} \\
(0.02)\end{array}$ & $\begin{array}{l}0.58^{* *} \\
(0.02)\end{array}$ & $\begin{array}{l}0.89^{* *} \\
(0.06)\end{array}$ & $\begin{array}{l}0.57^{* *} \\
(0.07)\end{array}$ & $\begin{array}{l}-0.45^{* *} \\
(0.08)\end{array}$ & $\begin{array}{l}1.71^{* *} \\
(0.18)\end{array}$ & $\begin{array}{l}0.67^{* *} \\
(0.03)\end{array}$ \\
\hline Barren uncult. Land & $\begin{array}{l}-0.15 \\
(0.013)\end{array}$ & $\begin{array}{l}-2.56^{* *} \\
(0.66)\end{array}$ & $\begin{array}{l}-0.56^{*} \\
(0.27)\end{array}$ & $\begin{array}{l}-1.28^{* *} \\
(0.09)\end{array}$ & $\begin{array}{l}-0.4^{* *} \\
(0.02)\end{array}$ & $\begin{array}{c}-1.08^{* *} \\
(0.1)\end{array}$ & $\begin{array}{c}-1.45^{* *} \\
(0.16)\end{array}$ & $\begin{array}{l}-0.72^{* *} \\
(0.03)\end{array}$ & $\begin{array}{l}-0.44^{* *} \\
(0.06)\end{array}$ & $\begin{array}{c}-1.56^{* *} \\
(0.1)\end{array}$ \\
\hline $\begin{array}{l}\text { Permanent pastures \& other } \\
\text { Grazing land }\end{array}$ & $\begin{array}{c}-0.01 \\
(0.014)\end{array}$ & $\begin{array}{l}-3.21^{* *} \\
(0.62)\end{array}$ & $\begin{array}{l}-0.06 \\
(0.18)\end{array}$ & $\begin{array}{l}-0.37^{* *} \\
(0.02)\end{array}$ & $\begin{array}{l}-0.69^{* *} \\
(0.01)\end{array}$ & $\begin{array}{l}-0.52^{* *} \\
(0.06)\end{array}$ & $\begin{array}{c}-0.49^{* *} \\
(0.1)\end{array}$ & $\begin{array}{l}-0.26^{* *} \\
(0.018)\end{array}$ & $\begin{array}{c}-0.76^{* *} \\
(0.2)\end{array}$ & $\begin{array}{l}0.28^{* *} \\
(0.05)\end{array}$ \\
\hline $\begin{array}{l}\text { Land under tree crops \& } \\
\text { Groves }\end{array}$ & $\begin{array}{c}1.51 \\
(1.15)\end{array}$ & $\begin{array}{c}0.18 \\
(0.86)\end{array}$ & $\begin{array}{l}10.25^{* *} \\
(3.03)\end{array}$ & $\begin{array}{l}-2.12^{*} \\
(0.86)\end{array}$ & $1.69(0.9)$ & $\begin{array}{c}-0.79^{*} \\
(0.3)\end{array}$ & $0.35(0.4)$ & $\begin{array}{l}1.71^{* *} \\
(0.58)\end{array}$ & $0.06(0.4)$ & $\begin{array}{l}1.72 * * \\
(0.38)\end{array}$ \\
\hline Land cultutable waste land & $\begin{array}{l}-1.76^{* *} \\
(0.220)\end{array}$ & $\begin{array}{l}-5.91 \\
(0.26)\end{array}$ & $\begin{array}{c}-1.15^{* *} \\
(0.06)\end{array}$ & $\begin{array}{l}-0.04 \\
(0.28)\end{array}$ & $\begin{array}{l}1.48^{* *} \\
(0.31)\end{array}$ & $\begin{array}{c}-1.29^{* *} \\
(0.13)\end{array}$ & $\begin{array}{c}-1.82^{* *} \\
(0.19)\end{array}$ & $\begin{array}{c}-1.26^{* *} \\
(0.04)\end{array}$ & $\begin{array}{c}1.68^{* *} \\
(0.2)\end{array}$ & $\begin{array}{c}-1.87^{* *} \\
(0.09)\end{array}$ \\
\hline Old Fallow lands & $\begin{array}{l}-0.81^{* *} \\
(0.168)\end{array}$ & $\begin{array}{l}2.9^{* *} \\
(0.39)\end{array}$ & $\begin{array}{c}0.19 \\
(0.21)\end{array}$ & $\begin{array}{l}0.71^{* *} \\
(0.18)\end{array}$ & $\begin{array}{l}-0.34^{*} \\
(0.16)\end{array}$ & $\begin{array}{l}-0.5^{* *} \\
(0.19)\end{array}$ & $\begin{array}{l}0.71^{*} \\
(0.2)\end{array}$ & $\begin{array}{l}0.67^{* *} \\
(0.13)\end{array}$ & $\begin{array}{l}1.11^{* *} \\
(0.16)\end{array}$ & $\begin{array}{c}0.11 \\
(0.17)\end{array}$ \\
\hline Current fallows & $\begin{array}{l}-0.11 \\
(0.38)\end{array}$ & $\begin{array}{c}0.06 \\
(0.65)\end{array}$ & $\begin{array}{l}-0.01 \\
(0.55)\end{array}$ & $\begin{array}{l}-1.06^{* *} \\
(0.27)\end{array}$ & $\begin{array}{l}-1.3^{* *} \\
(0.3)\end{array}$ & $\begin{array}{c}-1.42^{* *} \\
(0.3)\end{array}$ & $\begin{array}{c}-1.49^{* *} \\
(0.9)\end{array}$ & $\begin{array}{c}-0.86^{* *} \\
(0.25)\end{array}$ & $\begin{array}{c}-2.53^{* *} \\
(0.2)\end{array}$ & $\begin{array}{l}-2.03 \\
(0.4)\end{array}$ \\
\hline Net Area Sown & $\begin{array}{l}0.44^{*} \\
(0.20)\end{array}$ & $\begin{array}{c}0.23 \\
(0.12)\end{array}$ & $\begin{array}{l}1.17^{* *} \\
(0.24)\end{array}$ & $0.09(0.08)$ & $\begin{array}{c}0.26^{* *} \\
(0.1)\end{array}$ & $\begin{array}{l}0.23^{* *} \\
(0.08)\end{array}$ & $\begin{array}{c}0.14 \\
(0.07)\end{array}$ & $\begin{array}{l}0.31^{* *} \\
(0.05)\end{array}$ & $\begin{array}{c}1.06^{* *} \\
(0.1)\end{array}$ & $\begin{array}{l}0.28^{* *} \\
(0.06)\end{array}$ \\
\hline Total Cropped Area & $\begin{array}{l}0.84^{* *} \\
(0.29)\end{array}$ & $\begin{array}{l}1.4^{* *} \\
(0.35)\end{array}$ & $\begin{array}{l}1.66^{* *} \\
(0.26)\end{array}$ & $\begin{array}{l}0.69^{* *} \\
(0.12)\end{array}$ & $\begin{array}{l}0.79^{* *} \\
(0.19)\end{array}$ & $\begin{array}{l}0.92^{* *} \\
(0.17)\end{array}$ & $\begin{array}{l}0.94^{* *} \\
(0.12)\end{array}$ & $\begin{array}{l}0.43^{* *} \\
(0.11)\end{array}$ & $\begin{array}{l}1.62^{* *} \\
(0.25)\end{array}$ & $\begin{array}{l}1.61^{* *} \\
(0.19)\end{array}$ \\
\hline Area Sown more than once & $\begin{array}{l}6.62^{* * *} \\
(0.52)\end{array}$ & $\begin{array}{l}3.32^{* * *} \\
(0.39)\end{array}$ & $\begin{array}{c}10.02^{* *} \\
(0.72) \\
\end{array}$ & $\begin{array}{l}4.48^{* *} \\
(0.38)\end{array}$ & $\begin{array}{l}1.69^{* *} \\
(0.52)\end{array}$ & $\begin{array}{c}2.46 \\
(0.37) \\
\end{array}$ & $\begin{array}{c}2.16^{* *} \\
(0.2)\end{array}$ & $\begin{array}{c}0.64 \\
(0.35) \\
\end{array}$ & $\begin{array}{c}1.63^{* *} \\
(0.4)\end{array}$ & $\begin{array}{l}3.9^{* *} \\
(0.4)\end{array}$ \\
\hline
\end{tabular}

*5 percent level of significance and ${ }^{* *} 1$ Percent level of significance.

Figures in the parenthesis represent standard error

Table 2: CD-Valle Instability index of land use categories in different agro-climatic zones of Rajasthan

\begin{tabular}{|c|c|c|c|c|c|c|c|c|c|c|}
\hline & 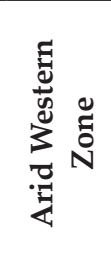 & 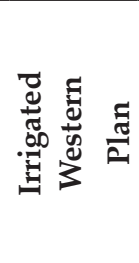 & 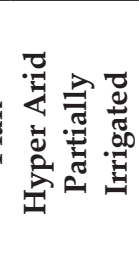 & 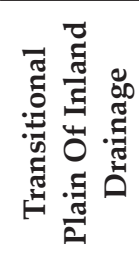 & 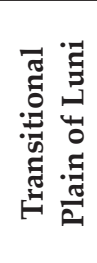 & 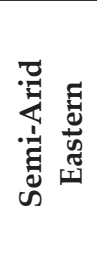 & 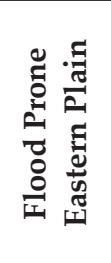 & 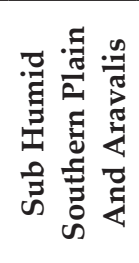 & 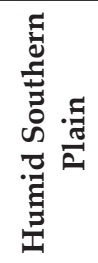 & 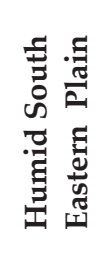 \\
\hline Forest & 10.41 & 26.33 & 11.77 & 12.49 & 4.56 & 4.53 & 2.54 & 7.26 & 15.47 & 7.58 \\
\hline Area under non-Ag. uses & 3.00 & 3.76 & 11.01 & 2.06 & 2.27 & 6.05 & 6.60 & 7.65 & 16.14 & 2.61 \\
\hline Barren uncult. land & 1.20 & 63.40 & 43.86 & 8.20 & 1.94 & 9.66 & 15.49 & 2.95 & 5.27 & 11.40 \\
\hline $\begin{array}{l}\text { Permanent pastures \& other } \\
\text { Grazing land }\end{array}$ & 1.37 & 52.05 & 15.55 & 1.77 & 1.36 & 5.91 & 14.53 & 1.57 & 18.41 & 4.08 \\
\hline Land under tree crops \& Groves & 124.40 & 154.38 & 134.08 & 97.86 & 92.22 & 37.45 & 39.37 & 50.53 & 31.24 & 43.51 \\
\hline Land cultutable waste land & 18.50 & 27.23 & 5.25 & 27.51 & 20.05 & 12.47 & 20.30 & 4.03 & 28.89 & 8.48 \\
\hline Old Fallow lands & 15.08 & 31.96 & 19.45 & 16.69 & 14.75 & 17.18 & 22.72 & 11.09 & 13.03 & 16.02 \\
\hline Current fallows & 44.68 & 71.93 & 82.49 & 30.23 & 35.97 & 28.12 & 51.94 & 23.21 & 22.14 & 58.49 \\
\hline Net Area Sown & 13.85 & 9.47 & 17.42 & 6.21 & 9.20 & 7.59 & 6.52 & 5.03 & 15.34 & 4.91 \\
\hline Total Cropped Area & 17.42 & 20.46 & 20.13 & 9.76 & 13.75 & 14.50 & 10.27 & 9.70 & 21.47 & 15.87 \\
\hline Area Sown more than once & 42.39 & 31.45 & 43.39 & 27.62 & 46.42 & 36.09 & 22.31 & 25.65 & 37.52 & 28.63 \\
\hline
\end{tabular}


into cultivable land. Barren uncultivated land (1.08), Land under tree crops and groves old fallows (0.5) reported decreased annual growth rate. Similar results of negative growth rate was also reported by Ahmed et al. (2018).

Analysis of compound growth rate for Flood Prone Eastern Plain of Rajasthan since 1973 depicted growth of 2.16 per cent in area sown more than once followed by forest $(1.34 \%)$, area under non agriculture uses $(0.57 \%)$, old fallows $(0.71 \%)$. Significant decrease in growth rate of area was noticed in land under uncultivable wastes $(1.82 \%)$, barren uncultivated land (1.45\%), permanent pastures and other grazing land $(0.49 \%)$. Similar pattern of results were reported by Ramaswamy et al. 2005).

Compound growth rate of land use categories in Sub Humid Southern Plain and Aravallis of Rajasthan reported significant and positive growth in land under tree crops and groves $(1.71 \%)$ followed byForest $(0.56 \%)$, total cropped area $(0.43 \%)$ and net sown area $(0.31 \%)$. Decreased growth rate was observed in land under cultivable waste $(1.26 \%)$ followed by current fallows $(0.86 \%)$, barren uncultivated land $(0.72 \%)$, area under non agriculture uses $(0.45 \%)$. Significant growth rate of forest and tree crops and groves may be due to the increased importance to the social forestry, agro forestry and other supportive programmes by government. Increase in area of old fallows considered major problem as it denoted the land left uncultivated for more than five years. Similar results were noted by Ramaswamy et al. (2005) and Gupta (2010).

Growth in land use categories of Humid Southern Plain of Rajasthan depicted significant and positive growth rate in tree crops \& groves. The increased area was highest in area under non agriculture uses $(1.71 \%)$. Land under cultivable wastes $(1.68 \%)$, Other land use categories such as area sown more than once $(1.63 \%)$, total cropped area $(1.62 \%)$, forest $(1.42 \%)$, old fallows (1.11\%). Net area sown (1.06 $\%)$ also had positive and significant growth rate. Negative and significant growth rate was reported in land use categories such as current follows $(2.53 \%)$, permanent pastures and grazing land $(0.76 \%)$ and land under barren and uncultivated land $(0.44 \%)$. The region has covered with dense trees and the recent programmes of planting trees also increased the area under Forest.

Growth rate of land use categories in Humid South Eastern Plain of Rajasthan reportedpositive and significant growth by area sown more than once $(3.9 \%)$, total cropped area increased $(1.61 \%)$, net area sown $(0.28 \%)$, land under tree crops and groves $(1.72 \%)$, forest $(0.66 \%)$ and area under non agriculture uses $(0.67 \%)$. Barren land $(-1.56 \%)$ and land under cultivable wastes $(-1.87 \%)$ showed significant decrease in land use area. The area sown more than once increased significantly which in turn increased the total cropped area. The soil in this region was productive and the rainfall experienced was high (700-1000 $\mathrm{mm}$ ) which contributed for the better agriculture practices and also forest area.

Instability Index: Instability represents the stability of time series data, thus instability of different land use categories in different agro-climatic zones was worked out and the results were delineated in the Table 2.

Instability index in arid western zone of Rajasthan reported high in land under tree crops and groves $(124.40 \%)$ whereas lowest instability was found in barren and uncultivated land (1.20\%). Instability index for irrigated North Western plain reported high in land under tree crops and groves (154.38\%) and lowest in area under non-agriculture uses $(3.76 \%)$.

Instability index for different land use categories in Hyper Arid Partial Irrigated Zone of Rajasthan reported high in land under tree crops \& groves $(134.08 \%)$ whereas lower instability was reported by cultivable waste land (5.25\%). Instability index for transitional plain of inland drainage of Rajasthan reported highest in land under tree crops and groves $(97.86 \%)$ and lowest in permanent pastures \& other grazing land $(1.77 \%)$. Instability index of land use categories in alluvial Plain of Luni Basin of Rajasthan reported high in the land under tree crops and groves $(92.22 \%)$ and low instability was reported by permanent pastures \& other grazing lands $(1.36 \%)$. Instability index of land use categories in Semi Arid Eastern Plain of Rajasthan was found highest in land under tree crops (37.45\%) and lowest instability was reported by forest $(4.53 \%)$. The stability in forest area during aforesaid study period was due to the changes in absolute value in these 
categories. Instability index of land use categories in Sub Humid Southern Plain and Aravallis of Rajasthan was highest in land under tree crops and groves $(50.53 \%)$ lowest instability was recorded for the permanent pastures and grazing land (1.57\%). The very highest or swollen data of area under tree crops and groves of above mentioned regions was because it also included some area of cultivated land occasionally and other trees such as bamboo and fodder crops. Hence the area varied frequently the instability index.

Instability index of land use categories in Humid Southern Plain of Rajasthan reported highest in area sown more than once $(37.52 \%)$ and lowest in barren and uncultivated land (5.27\%). Instability index of land use categories in Flood Prone Eastern Plain of Rajasthan reported highest in current fallows $(51.94 \%)$ and low instability reported by forest $(2.54 \%)$. This might be because of year to year fluctuations in current fallows was common. Instability index of land use categories in Humid South eastern Plain of Rajasthan for the present study period reported highest in current fallows (58.49\%) and lowest instability was reported by area under non agricultural uses with (2.61\%). Current fallows vary year to year and hence fluctuations reported were more. Area under non agriculture uses related to the development structures, house construction roads etc which were permanent nature and hence hard to change the usage of land to other purpose. Therefore instability or changes over time is low.

\section{CONCLUSION}

The ongoing discussion on land use changes in different agro-climatic zones of Rajasthan revealed that area under forest increased significantly in all regions except for Sub Humid Southern Plain and Aravalis for which it decreased significantly. Total cropped area, area sown more than once reported significant and positive change in all regions area under non-agricultural uses also increased significantly in all regions. It depicted that agriculture development and infrastructure development both are improving parallel in all regions of Rajasthan. Significant decrease in current fallow land in most of the agro climatic region followed by positive increase in old fallow land in corresponding region is a serious problem which has to be addressed for bringing the old fallow land back to cultivation and preventing them to convert into non-agriculture purposes. Decreased permanent pastures might have shifted to nonagriculture and agriculture area as reported by increased trend in these categories.

Instability in Land under tree crops \& Groves for all regions reported high area under current fallows and area sown more than also showed more fluctuations. This might because of the rainfall variability, global warming that caused the agriculture land to leave uncultivated. Area under net sown are showed less variability in all regions. Policy like improving ground water table through construction of agriculture ponds, contour bonds under MGNREGA might help the farmers in shifting fallow land to cultivation.

\section{REFERENCES}

Adhikari, A. and Sekhon, M.K. 2014. An economic analysis of land use dynamics in Punjab. Int. J. Adv. Res., 2: 551-560.

Ahmad, N., Sinha, D.K. and Singh, K.M. 2018. Changes in land use pattern and factors responsible for variation in current fallow land in Bihar. Indian J. Agric. Res., 52: 236-242.

Aravind, K. 2010. Economics of land use and cropping pattern in northern transitional zone of Karnataka. M. Sc. (Agri) Thesis, Univ. Agric. Sci., Dharwad, Karnataka (India).

Bardhan, D. and Tewari, S.K. 2010. An investigation into land use dynamics in India and land under-utilisation. Indian J. Agric. Eco., 65: 658-676.

Gairhe, S., Kulkarni, G.N. and Reddy, S.V. 2011. Land Use Dynamics in Karnataka: Post Economic Liberalization. Res. J. Agric. Sci., 2: 921-923.

Goswami, S.N. and Challa, O. 2004. Indian Land use scenario: An overview. Agric. Situa. India, 60: 783 - 797.

Gupta, S. and Sharma, R.K. 2010. Dynamics of land utilization, land degradation and factors determining land degradation in Himachal Pradesh. Indian J. Agric. Eco., 65: 245-260.

Harish, M.H. 2006. An appraisal of land use dynamics in Mandya district. M. Sc. (Agri) Thesis, UAS, Dharwad, Karnataka (India).

Jangid, M.K., Sharma, L., Burark, S.S. and Jain, H.K. 2018. Land use pattern, cropping pattern and resource use efficiency in arid western plain zone of Rajasthan. Indian J. Ext. Edu., 26: 56-61.

Nagabhushan, C.A. 1994. Dynamics of land use in Dharwad district, M. Sc.(Agri.) Thesis University of Agricultural Sciences, Dharwad, Karnataka (India).

Pushpa, C.O. and Akashraj, D.P. 2014. An investigation into land use dynamics in Karnataka-an ecological perspective. Merit Res. J. Agric. Sc. and Soil Sci., 2: 047-052. 
$\underset{\text { AESSRA }}{\mho}$ Thanuja et al.

Ramasamy, C., Balasubramanian, R. and Sivakumar, S.D. 2005. Dynamics of land use pattern with special reference to fallow lands-an empirical investigation in Tamil Nadu. Indian J. Agric. Eco., 60: 629-644.
Wani, M.H., Baba, S.H. and Yousuf, S. 2009. Land use dynamics in Jammu and Kashmir. Agric. Eco. Res. Rev., 22: $145-154$. 